\title{
The International Rule of Law and the Idea of Normative Authority
}

\section{Kostiantyn Gorobets ${ }^{1}[$}

Published online: 16 March 2020

(C) The Author(s) 2020

\begin{abstract}
Domestic and international jurisprudence exist and develop as two 'pocket universes' in a sense that they belong to the same fabric of reality, but at the same time many concepts shift their meaning when moved from one pocket to another. This is of a paramount importance for the idea of the rule of law, which in domestic setting was forged in the flame of civil wars and struggles against the rulers. This history and such struggles are something international law has never known, and thus any direct transplantation of the domestic images of the rule of law to international realm are doomed to fail. This entails a need in deconstructing the rule of law. Its core meaning ('laws must be obeyed'), brings a normative claim relevant to any legal order. The idea of the (international) rule of law appears to be linked to the idea of authority of (international) law. There are differences of the structures of authority in domestic and international law as authority can be mediated or unmediated. Mediation of authority, typical for domestic law, presupposes the existence of officials that are functionally and institutionally differentiated from the subjects of law. Authority of international law is by and large unmediated because of its horizontal nature. Such reconstruction allows to reframe the central concern of the international rule of law enquiries. Instead of trying to fit it to the procrustean bed of domestic theories, international legal scholarship must focus on defining conditions under which international law's claim to authority is realisable.
\end{abstract}

Keywords International rule of law $\cdot$ Authority of international law $\cdot$ Normative authority $\cdot$ Legal normativity

Kostiantyn Gorobets

k.v.gorobets@rug.nl

1 Department of Transboundary Legal Studies, University of Groningen, Groningen,

The Netherlands 


\section{Introduction}

In the recent decades, the international rule of law $^{1}$ has become a topical yet conceptually challenging idea. The internationalisation of the rule of law has a wide spectrum of applications, from its promotion through a variety of international organisations $^{2}$ to attempts to implement it as a legal ideology for international law as such, ${ }^{3}$ for example, through its inclusion into Agenda-2030. ${ }^{4}$ Often the meaning and function of the international rule of law is assumed, yet what 'the international rule of law' means and what practical differences it entails when we add 'international' to 'the rule of law', and how and why it should be protected remains unclear. Despite

\footnotetext{
${ }^{1}$ In this article I approach the rule of law as a jurisprudential concept and specific legal ideology, and not as a legal practice. Ideologies are frameworks we use to justify or question social practices, and this is exactly the function the rule of law performs. It is a meta-normative ideal that reflects the merits of a legal order functioning in a way which enables its subjects to comply with it and use it as a guidance for actions. The international rule of law, therefore, applies to the normative powers which international law exercises in relations between states, as well as in relations between international organisations and states, in relations between states and individuals, and even in relations between international organisations and individuals (Kanetake 2016, p. 16). This article, however, mostly focuses only on one-horizontal-dimension of the international rule of law. There are two main reasons for such a limitation. First, it is beyond the scope of a stand-alone publication to cover all the faces and angles of the international rule of law. Second, the horizontal image of the international rule of law is most theoretically challenging since it questions the very fundamental assumptions regarding the rule of law (see Sect. 1), and it also appears to be the most generic. Therefore, I believe that the conceptual framework offered here accounts for other manifestations and contexts of the international rule of law as well.

2 The United Nations, Council of Europe, European Union, World Bank, and so forth often articulate the critical role of the rule of law and emphasise the need of its strengthening by national governments. What unites all these activities is that the rule of law is presented in its domestic meaning. This is also true for the often cited definition of the rule of law by the UN Secretary-General, that 'it refers to a principle of governance in which all persons, institutions and entities, public and private, including the State itself, are accountable to laws that are publicly promulgated, equally enforced and independently adjudicated, and which are consistent with international human rights norms and standards. It requires, as well, measures to ensure adherence to the principles of supremacy of law, equality before the law, accountability to the law, fairness in the application of the law, separation of powers, participation in decisionmaking, legal certainty, avoidance of arbitrariness and procedural and legal transparency.' 'Report of the Secretary-General on the rule of law and transitional justice in conflict and post-conflict societies' (12 October 2011), UN Doc S/2004/616, para. 6. As Robert McCorquodale notices, 'it is a statement about how the rule of law should operate in national systems and it is not a definition of the rule of law at the global level' (McCorquodale 2016, p. 286). Also, Rule of Law Checklist, adopted by the Venice Commission in 2016 (Venice Commission, 'Rule of Law Checklist' (18 March 2016) CDL-AL(2016)007) has been specifically designed as 'a tool for a variety of actors who may decide to carry out... an assessment' of rule of law practices (para. 26-27). The UN's 'Rule of Law Indicators' focuses primarily on how the rule of law should be implemented by national governments. The United Nations Rule of Law Indicators: Implementation Guide and Project Tools (New York: United Nations, 2011), vi.

${ }^{3}$ See 'Declaration of the high-level meeting of the General Assembly on the rule of law at the national and international levels', UNGA Res 67/1 (24 Sep. 2012) UN Doc A/RES/67/1, para. 2: 'the rule of law applies to all States equally, and to international organizations, including the United Nations and its principal organs, and that respect for and promotion of the rule of law and justice should guide all of their activities and accord predictability and legitimacy to their actions'.

4 'Transforming our world: the 2030 Agenda for Sustainable Development' UNGA Res 70/1 (21 Oct. 2015) UN Doc A/RES/70/1, goal 16.3.
} 
many attempts of conceptualising the international rule of law, ${ }^{5}$ it still lacks shape and appears as a nebulous ideal.

This contribution offers a framework for conceptualising the international rule of law as a meaningful idea. It suggests that the international rule of law, its meaning and function, should not be deduced from the rule of law known domestically. Instead, the two versions of the rule of law should be deconstructed and stripped down of the variety of political, moral, and other layers in order to reveal their common core. The contribution will submit that this core meaning relates to the normative authority any legal order claims and to the conditions under which this claim becomes realisable.

The article will proceed in three steps. I first sketch out an image of the rule of law known domestically and show why it is not appropriate to transplant its theories and underlying histories directly into international law (Sect. 1). In Sect. 2, I show that theories of the rule of law must be deconstructed in order to reveal their core concern which, it will be submitted, relates to the normative authority. Finally, I present the international rule of law as a set of conditions under which international law's claim to authority is realisable (Sect. 3).

\section{The International Rule of Law Between Two ‘Pocket Universes'}

Like many other normative ideals, the conceptual shape and meaning of the rule of law, as well as critical points of disagreement over its content, are products of domestic jurisprudential and political discourse. It is, therefore, well known that the idea and the concept of the rule of law strongly relate to how state government and other public authorities affiliated with it may or may not exercise their political powers. Hence a canonical three-headed picture of the rule of law offered by Albert Dicey: (1) predominance of regular laws as opposite to arbitrariness; (2) equality before the law; and (3) institutional protection of rights (Dicey 1959, p. 201-203).

The main concern surrounding the rule of law may be phrased in many different ways: securing individual autonomy, guaranteeing respect for human dignity, providing for accountability of governmental agencies, limiting arbitrariness in execution of power, etc. But overall these ideas can be reduced to the principle that there must exist certain limits for the use of law, or as framed by Joseph Raz, the rule of law defends against threats coming from the law itself ( $\operatorname{Raz} 2009$, p. 224). Law is one of the ways political power is exercised, and thus the rule of law is a virtue of a certain legal order. The main theoretical concern about the rule of law is how broad this virtue is in terms of the scope of its particular requirements. Though Dicey's threefold approach is a common starting point for rule of law discussions, it does not exhaust the varieties of conceptions-broad and narrow-of this idea. Therefore, the critical point of theoretical disagreements about the rule of law is whether it accounts only for what is known as formal legality or also encompasses requirements regarding the content of rules.

\footnotetext{
5 See below, Sect. 1.
} 
On the one hand, it is often claimed that the rule of law is only $a$ virtue of a legal system, and there are other virtues a legal system may or may not possess, or may possess to a lesser or higher degree. Hence, in this conception the rule of law only relates to the principles which represent the idea of formal legality, i.e. a set of requirements as to how laws should function. To say that a legal system conforms to the rule of law implies, from this perspective, that its laws are clear enough, known in advance, and relatively stable; that they do not prescribe the impossible and do not apply retrospectively; that their making is guided by clear, known, and stable rules; that all these rules are equally and consistently applied; that they are general and do not select particular individuals or make irrelevant distinctions between people; that courts are accessible and allowed to review governmental directives, etc. ${ }^{6}$ This view embodies in 'thin' or formal conceptions of the rule of law. ${ }^{7}$ The main claim of these theories is that the rule of law only relates to formal features of laws composing a given legal system and does not impose requirements regarding their content. ${ }^{8}$ In such a way, 'thin' theories strictly separate the rule of law as a virtue of a legal system from other virtues, such as goodness or justness of its laws. The rule of law, in other words, does not by definition mean the rule of good law.

On the other hand, the rule of law is often taken as a much broader ideal. It is thus framed not merely $a$ virtue of a legal system, but the moral and political ideal that embraces principles and values which form an image of a better society. From this perspective, it is not enough to secure a specific way or method in which law operates, and for this reason the rule of law must mean more than just formal legality. The rule of law, it is therefore submitted, must be furthered not only for the motives of legal certainty and predictability but also for the motives of higher values, such as

\footnotetext{
6 There are many similar versions of such a list of requirements of the rule of law (von Hayek 2012; Raz 2009, p. 214-219), and it is beyond the scope of this paper to discuss them in depth. For a supplementing view, see Lon Fuller (1978, ch. 2). Unlike Raz, Fuller claims that a minimal conformity to the rule of law is required as a necessary condition of existence of a legal system, which reflects the disagreement they have on the nature of legality. This issue cannot be discussed here.

7 Here, I follow the classification of the rule of law conceptions offered by Paul Craig and Brian Tamanaha (Craig 1997, p. 467-487; Tamanaha 2004, ch. 7-8). Similar though critical towards classical approaches classification may be found in Paul Gowder's work, where he labels them as 'weak' and 'strong' rule of law, respectively (Gowder 2016, ch. 1-3).

${ }^{8}$ I do not suggest here that the formal rule of law does not create any substantive implications. This is the whole point why we value the rule of law: it makes a practical difference for how legal orders operate, which necessarily affects the content of their laws. It is, then, a natural assumption that there is a correlation here: the better a legal order conforms to formal requirements of the rule of law, the higher are chances that its particular laws are more just and fair. As David Lubman shows, Fuller's canons of the rule of law, though they are formal, nevertheless necessarily imply at least some substantive limitations and 'push the law away from a certain kind of moral badness' (Lubman 2010, p. 39). A similar line of argument found in Paul Gowder: the formal conceptions of the rule of law must contribute to achieving certain substantive aims (e.g. keeping officials from abusing their powers), otherwise they are just hollow (Gowder 2016, pp. 48-51). Although I agree that the rule of law allows us to secure certain moral values which would otherwise be jeopardised, I believe this does not imply that such moral values must necessarily be elements of the rule of law as such.
} 
human dignity, democracy, equality, justice, liberty, etc. ${ }^{9}$ Ronald Dworkin famously claimed that

the rule of law on this conception is the ideal of rule by an accurate public conception of individual rights. It does not distinguish ... between the rule of law and substantive justice; on the contrary it requires, as part of the ideal of law, that the rules ... capture and enforce moral rights (Dworkin 1985, p. 11-12).

Taken in such a broad, or 'thick', meaning, the rule of law is no longer just a quality of a legal system. It becomes a complex and multidimensional ideology, 'too important to be left to lawyers' (Krygier 2012, p. 30) ${ }^{10}$ In this all-inclusive manifestation the rule of law appears as an element of a theory of justice, and not just as a set of formal requirements for laws, and for this reason conceptions of the rule of law that share this perspective are often labelled as 'thick' or 'substantive'.

The 'thin' and the 'thick' versions of the rule of law are sometimes seen as complementary standards,${ }^{11}$ and sometimes as contradictory or at least conceptually incompatible. ${ }^{12}$ But what is more important is that regardless how the 'thin' and 'thick' visions of the rule of law correlate with each other, they are products of domestic legal experience and practice. The whole logic of describing the rule of law in between these two traditions results from contemplating the rule of law as a political and legal doctrine of protecting citizens against governmental abuses. The only principal difference is that the 'thin' theories do this through establishing safeguards as to how laws should be given a proper functionality, and the 'thick' theories through ensuring that laws substantively reflect the values and principles underlying individual rights. Is it possible to transplant this logic to international law, or should the international version of the rule of law be approached differently? The critical issue of the concept of the international rule of law is what it means for the rule of law to be (truly) international? Is it the same rule of law? Can we appropriately attach the same meaning to it as we do to the rule of law known domestically? ${ }^{13}$

\footnotetext{
${ }^{9}$ E.g., the much-celebrated Lord Bingham's account on the rule of law led him to a famous conclusion that the rule of law is 'the nearest we are likely to approach to a universal secular religion' (Bingham 2011, p. 172). He believes, among other things, that the rule of law must require protection of fundamental human rights, which also implies that the rule of law is hardly possible without democracy (Bingham 2007).

${ }^{10}$ That 'the rule of law is too important to be left to lawyers' is Martin Krygier's paraphrase of David Shipler's 'law it too important to be left to lawyers', which in its turn is a paraphrase of Georges Clemenceau's 'war is too important to be left to generals'.

${ }^{11}$ E.g., for Gowder, the thick (or 'strong', in his own language) version of the rule of law applies to the enactment of law and the use of discretion in its interpretation, whereas the thin ('weak') version-to its execution (Gowder 2016, p. 51).

${ }^{12}$ Craig summarises this latter point by saying that 'the adoption of a fully substantive conception of the rule of law has the consequence of robbing the concept of any function which is independent of the theory of justice which imbues such an account of law' (Craig 1997, 487). See also John Tasioulas who observes that deducing the rule of law from one or another normative ideal-liberty, justice, right, etc.only obscures its meaning and makes it indistinguishable from what it means for law to be a good law (Tasioulas 2018).

${ }^{13}$ In one form or another, these issues are central for the most attempts of conceptualising the international rule of law (Beaulac 2007; Burgees 2019; Chesterman 2008; Collins 2019; Hurd 2015b; McCorquodale 2016; Nardin 2008; Pavel 2019).
} 
One of the leading approaches to the concept of the international rule of law suggests that one can grasp its meaning and function in the international community by applying the template designed on the basis of, and applied to, the rule of law known domestically. It is thus often assumed that applying the logic of the rule of law to international law entails matching it to one of the lists of criteria offered by Dicey, Fuller, Raz, or other scholars, and then either try to stretch them to account for peculiarities of international law (Beaulac 2007; Crawford 2003; Sampford 2014) or reject the international rule of law altogether as unsound (Hurd 2015b). ${ }^{14}$ International law is in principle unable to satisfy some of these criteria, which either means the rule of law does not apply here, or that international law is simply deficient (Hurd 2015a). It is therefore claimed that international law is too underdeveloped and primitive, and for this reason 'there is presently no such thing as the international rule of law, or at least that international law has yet to achieve a certain normative or institutional threshold to justify use of the term' (Chesterman 2008, p. 358). Some authors even go further and observe that 'talk of a rule of law for the international realm cannot target law in the usual sense of the term' (Pavel 2019, p. $3)$.

In such a way, the most conceptual problems related to the international rule of law are connected to theorising its meaning, content, and functions through the use of the domestic analogy. This domestic analogy, however, does not seem to be justified, if only because the rule of law-domestic or international-must be taken as a product of certain legal histories. ${ }^{15}$ As nicely put by Jutta Brunnée and Stephen Toope,

the problem with the domestic law analogy is not necessarily the analogy as such, but the assumptions that commonly shape it. When we assume that the defining features of domestic law — and by extension of all law - are formal enactment by a superior authority, application by courts, and centralized enforcement, we are bound to see international law as a poor cousin. Most

\footnotetext{
${ }^{14}$ Hurd's rejection of the international rule of law as a normative doctrine is based on the idea that the international rule of law should be approached descriptively, i.e. the international rule of law is a toolbox of justificatory means states exploit to defend their policies (Hurd 2014).

15 The inappropriateness of the domestic analogies regarding inter alia rule of law issues was stressed already by ICTY, where the Tribunal emphasised that 'the international community lacks any central government with the attendant separation of powers and checks and balances. In particular, international courts, including the International Tribunal, do not make up a judicial branch of a central government. The international community primarily consists of sovereign States; each jealous of its own sovereign attributes and prerogatives, each insisting on its right to equality and demanding full respect, by all other States, for its domestic jurisdiction. Any international body must therefore take into account this basic structure of the international community. It follows from these various factors that international courts do not necessarily possess, vis-à-vis organs of sovereign States, the same powers which accrue to national courts in respect of the administrative, legislative and political organs of the State. Hence, the transposition onto the international community of legal institutions, constructs or approaches prevailing in national law may be a source of great confusion and misapprehension. In addition to causing opposition among States, it could end up blurring the distinctive features of international courts.' Prosecutor $v$ Blaškić (Judgement in the Appeals Chamber) ICTY-IT-95-14 (29 October 1997), para 40. Cf to the view of Martti Koskenniemi, who claims that "the "domestic analogy" ... is necessarily entailed by the modern system of international law’ (Koskenniemi 2006, p. 22).
} 
importantly, we risk misjudging how law operates in international society, obscuring its potential power, and misdirecting even the best intentioned efforts to improve it (Brunnée and Toope 2010, p. 6).

And indeed, it is essential to appreciate that domestic and international versions of the rule of law were shaped as responses to quite different challenges. The relevance of the rule of law as a legal ideology for domestic setup was forged in civil wars, revolutions, bills of rights, and oppositions to the powers of kings, princes, and nobles-something that international law has never known. It seems that the only way of taking the international rule of law seriously is by rejecting the transplantation of legal histories and the political ideologies from the domestic to the international realm. Though histories of domestic law and histories of international law overlap, it does not mean that they are shared. The histories of international law comprise tales of preventing and reducing suffering in wars, guaranteeing the autonomy of states, securing their coexistence and cooperation, achieving solidarity and furthering common goals, but also of fighting for sovereign equality and liberation. ${ }^{16}$ Hence though some motives in the historical narratives of domestic and international law may somehow echo one another, ${ }^{17}$ their general structures and story-lines differ quite significantly. As Paul Burgees convincingly argues, even though evolutions of domestic and international rule of law seem to suggest similar solutions, this does not mean they grew from similar problems (Burgees 2019, p. 78-79). ${ }^{18}$

Domestic and international law, in such a way, exist and develop like two 'pocket universes'. This term relates to a hypothesis shared by some astrophysicists that our reality is not continuously uniform, and that it rather looks like a 'patchwork quilt' with each part having somewhat different fundamental parameters (Guth 2000). Thus one 'pocket universe' may differ from another in some basic prerequisites, which results in further diversification as they develop. They still belong to the same fabric of reality, and may even share many characteristics, but the way things appear in them features dissimilarities. This idea describes quite accurately the relations between domestic and international jurisprudence. They both belong to the same reality, but at the same time form two distinct 'pocket universes', which affects the meaning and functions of many shared concepts and ideas. This is primarily because domestic and international jurisprudence have dissimilar agendas dictated not only

\footnotetext{
16 There can much be said about the transformation of historical discourses of international law, see (Koskenniemi 2016). This, however, is not the task of this article. My point here is that the struggle for international law (to use von Jhering's language) differs from the struggle for law in the domestic setup.

17 One could see similarities in the domestic political struggles against racial inequality (especially in the USA and South Africa) and international political struggles against colonialism, which furthered the ideology of the rule of law and gave it a refreshed meaning. Both were driven by the ideology of equality and contra suppression and domination (Anghie 2005; Pahuja 2011).

18 I also share Paul Burgees ultimate analytical conclusion stemming from the historical argument: 'Given the absence of a domestic Rule of Law concept formed in relation to the same problems as those present in the international sphere, the rationale for using a domestic idea-or a modified version of that idea-as a foundation for the creation or identification of an international Rule of Law does not subsist. As those problems do not correlate, domestic Rule of Law conceptions should not be used as the foundation from which to derive an international Rule of Law' (Burgees 2019, p. 66).
} 
by well-known structural and functional differences between the two types of legal orders, ${ }^{19}$ but also by divergent challenges faced by domestic and international law. The convergence of these challenges in recent decades, though, is a reason why the rule of law has been more actively articulated as applicable to international affairs.

The conceptual problem of the rule of law as a product of particular legal histories becomes visible when assessed against this idea of 'pocket universes'. The two share many concepts and ideas, yet in most cases each jurisprudential universe has its own conventional way of using and applying them. This can be said, for instance, about concepts of 'custom', 'bindingness', 'obligation', 'validity', and many more. Though featuring in both universes, they are accompanied by somewhat dissimilar techniques of instrumentalisation; they, if we continue our astrophysics metaphor, 'vibrate' on different 'frequencies'. The same can also be said about the rule of law. As stated by Arthur Watts,

for at least two reasons these national notions of the rule of law cannot be directly transposed to the international level. First, the purposes which the rule of law serves at the national level-usually involving the protection of the rights of the individual as against an otherwise all-powerful governing authority - are quite different from those which it might be called upon to serve internationally; and second, the more specific requirements of the rule of law often reflect a State's particular historical and constitutional evolution, and differ from State to State. The international rule of law cannot be identified with any one national meaning of the concept... (Watts 1993, p. 16).

And indeed, the histories of the domestic rule of law relate to the ideas that individuals must have normative and institutional safeguards that defend them against governmental abuses, which in itself assumes a hierarchical relation between the ruled and the ruler. Whom does the international rule of law defend then, and against whose abuses? Certainly, it can be said that in the case of the international rule of law, just like with it domestic sibling, its ultimate beneficiaries are individuals; that states mediate between international law and people replicating in such a way the hierarchical scheme of government (Waldron 2011). ${ }^{20}$ It is a solid perspective, which, however, only takes one of the possible dimensions of the international rule of law. Even though international law and international institutions have been increasingly addressing natural persons, which naturally creates the rule

\footnotetext{
19 Here, I refer to the horizontal structure of international law that manifests in the absence of universal legislative, judiciary, and executive. Even though some domestic legal systems may not feature them as separate and institutionally independent branches of government, their functions are performed by a legal system, nevertheless.

20 'Ultimately the reasons for continuing to insist that ROL [rule of law] requirements apply to the nation-state are the same as they always are. Those requirements apply to the state for the sake of the well-being, liberty, and dignity of individuals' (Waldron 2011, p. 341). In such a way, for Waldron, the rule of law applied internationally has little difference in structure as compared to the rule of law applied domestically; in both cases it ultimately benefits human individuals by being mediated through officials of nation states (Waldron 2011, p 332).
} 
of law related concerns, ${ }^{21}$ it seems too far-fetching to boil down all possible manifestations of the international rule of law only to this kind of relations. It may be too early to reject the paradigm that states are the primary subjects of international law and hence beneficiaries of the international rule of law, which makes the hierarchical perception of this doctrine far less relevant. Since there is no government states require protection from, there is seemingly little point in framing the international rule of law concerns in such a way. ${ }^{22}$ Yet it does not mean that these concerns are no longer relevant. As convincingly argued by Martin Krygier, the main goal of the rule of law is to limit arbitrariness in execution of power (Krygier 2018, p. 149-152) - a concern which is as valid in international law as it is in domestic legal systems. States obviously may use their powers to abuse other states, without being formally superior to them. This makes the horizontal dimension of the international rule of law as relevant as canonical vertical ones. And yet there seems to be little understanding of how horizontal and vertical manifestations of the international rule of law can be reconciled within one conceptual paradigm.

Does this mean that the international rule of law is merely an empty political slogan, which has in fact no meaning? Or perhaps international law is way too special and therefore any attempt to conceive it through the prism of the rule of law will fall victim of unacceptable distortions? These questions are tough ones because they address the very problem of extended applicability of a certain normative ideal beyond its native domain. The next section will address these questions by reconstructing the core meaning of the rule of law common to its domestic and international manifestations.

\section{Attempting Reverse Engineering: the Rule of Law and Normative Authority}

The conceptual challenge posed by the international rule of law is of a complex nature. First of all, it impeaches the underlying assumptions most classical doctrines of the rule of law rely on (such as that the rule of law is addressed to officials and thus implies a formal hierarchy, or that it entails separation of governmental functions, or that it primarily safeguards individual autonomy). Further, the international iteration of the rule of law presupposes the universal validity of this concept, yet as was shown, the direct transplantation of its domestic vision to the international law does not seem a promising strategy. In such a way, to admit that the rule of law may

\footnotetext{
21 The Kadi case is a canonical example in this regard. Case C-402/05 P and C-415/05, P. Kadi and Al Barakaat International Foundation v. Council and Commission [2008] ECR I-6351.

22 Waldron states that if we accept this latter vision of the international rule of law, i.e. as applied primarily to states as subjects of international law, it becomes redundant. For if there is nothing states may in principle be abused by, the whole concern of the rule of law may be avoided (Waldron 2011, p. 323). See also Allen Buchanan, who believes that "much of IL concerns the relations among states and in many cases, states do not represent the interests of some or even most of their citizens. So, it is not clear just how the commitment to the rule of law is to be cashed out in the international arena' (Buchanan 2006, p. 314-315).
} 
apply internationally implies to abandon the traditional images of this idea and to try to discover its core, common for all its possible manifestations.

In order to contemplate the international rule of law we need to abstract from its domestic model and attempt its reconstruction or 'reverse engineering'. What reverse engineering requires is a deconstruction of the conceptual layers of the rule of law that came as a consequence of domestic contestation of this ideal. Deconstructing the core meaning of the rule of law without linking it directly or indirectly to the domestic rule of law theories and practices chiefly implies abstracting from its moral and political justifications. ${ }^{23}$ Being stripped down of these justifications, however, the rule of law has a seemingly trivial content. Joseph Raz offers, probably, the most straightforward formulation of the truism that underlies the rule of law when he submits that " "the rule of the law" means literally what it says: the rule of the law. Taken in its broadest sense this means that people should obey the law and be ruled by it' (Raz 2009, p. 212). This implies that the rule of law, taken domestically or internationally, does not have any direct moral message, as is sometimes assumed. ${ }^{24}$

This core formula of the rule of law may seem way too simplistic. For if the rule of law only means recognition of the normative force of the law and obedience to it, then even the formal legality requirements appear as a redundant set of principles. Yet importantly, saying that the law ought to be obeyed and people should be guided by it is also assuming many other things which are often taken exactly as the requirements of the rule of law. For the people to obey the law, it must be capable of being obeyed. ${ }^{25}$ They must at least know what it is, how to identify it, and how to extract its normative meaning. No-one can obey norms he is not aware of, or norms that prescribe the impossible, or norms presented in a language its subjects cannot understand. This does not mean that such norms cannot exist or cannot be enforced upon their subjects. ${ }^{26}$ However, a legal order consisting only of such norms would

\footnotetext{
${ }^{23}$ The methodological approach of reverse engineering as applied to international law differs significantly from other two common approaches, identified by Paul Burgees: (1) deployment and amendment or augmentation of pre-existing rule of law conceptions; and (2) application of the rule of law to the international rule of law by co-identification of similar or related features across the two-international and domestic — concepts (Burgees 2019, p. 90-94).

${ }^{24}$ For example, Terry Nardin writes that the criteria of the rule of law 'presuppose a primary order of non-instrumental rules in which citizens are related to one another as moral equals', and thus 'the rule of law means that states treat one another justly, that is, as members of an association constituted by their recognition of the authority of its rules' (Nardin 2008, p. 399). This interpretation explicitly presupposes a moral meaning of the (international) rule of law, which is problematic. Is the international rule of law only satisfied when states treat each other as equals or behave justly? Does not it say something about the moral merits of states in question rather than merits of international law as such?

${ }^{25}$ A similar point has also been argued by David Dyzenhaus, who claims that the central question of the rule of law is 'how it is possible that those subject to the de facto power of a sovereign could consider his enacted law as obligatory — as having de jure or legitimate authority over them', that is, 'Why should the law be considered a source of obligations in the first place?' (Dyzenhaus 2014, p. 54). Dyzenhaus then proceeds with an argument that a realist-style skepticism about the international rule of law, which is often attributed to Hobbes, does not, in fact, hold.

${ }^{26}$ In this situation, this will still be law, but it would become practically indistinguishable from a sheer power or violence. For subjects to comply with it, they will need first deduce the normative meaning of the actions of officials by observing their reactions to some events or lines of behaviour. This entails that even in such a crooked and violent society, at least officials must share a more or less common understanding of law, otherwise it will be impossible to enforce.
} 
probably not last for long even if coercively imposed. ${ }^{27}$ In other words, for a subject of law to obey norms, these norms must have qualities that create practical opportunities for obedience.

In this way, the rule of law is a merit of a legal order that enables its subjects to comply with it. ${ }^{28}$ This merit, however, may be implemented in more than just one way. Depending on how a legal order operates, what normative claim it has, to whom it is addressed, and so on, its content and structure changes. The rule of law, from this point of view, should be perceived as coalescing two perspectives: one is the perspective of the subjects (bottom-up) and the other is the perspective of legal order as such (top-down). The function and the value of the rule of law, therefore, is that it serves a bridge between law's claim of authority over its subjects, and actual materialisation of this claim in their conduct. Thus, if we accept that the rule of law relates to the ability of a legal order to generate an acceptable and realisable claim of authority, the theory of the rule of law becomes part and parcel of the theory of authority of law. This entails that our attempted deconstruction of the rule of law must also include ascertainment of what this claim actually is and how it may be realised.

International law, like any other legal order, claims to have an authority in a sense that it provides its subjects with reasons for actions they ought to comply with. Yet what does that claim of authority comprise? Why is it relevant to ensure that this claim is actually convertible into compliance?

Authority is a special kind of relation between the law and its addressees. ${ }^{29}$ What is special about this relation is that authority affects the practical reasoning of its subjects. To say that A has an authority over B means to say that A may address to $\mathrm{B}$ directives which $\mathrm{B}$ ought to obey. ${ }^{30}$ There are many examples of such relations:

\footnotetext{
27 This is, of course, a matter of degree and social context. I am not assuming that a Fullerian thesis that the minimal conformity to the rule of law (inner morality of law in his own language) is a necessary condition for existence of law is accurate. However, some authors tend to adopt this position (Nardin 2008, p. 400-401).

${ }^{28}$ Cf Michael Oakeshott's idea that 'the expression "the rule of law" [...] stands for a mode of moral association exclusively in terms of the recognition of the authority of known, non-instrumental rules (that is, laws) which impose obligations to subscribe to adverbial conditions in the performance of the self-chosen actions of all who fall within their jurisdiction' (Oakeshott 1983, p. 148). I do not indent to show that the rule of law imposes obligations on actors (although this is often the case), rather, I aim to suggest that it enables actors to accept and abide by obligations to begin with.

29 In my approach to authority in this section, I largely follow the service conception of authority by Joseph Raz, developed in a series of books (Raz 1986, 1999, 2009). This conception has its limitations, however. Raz focuses primarily on the institutional meaning of authority (authority as some organ) and does not pay much attention to the authority claimed directly by the law. He recently confirmed his view that authority of international law should also be seen institutionally ( $\operatorname{Raz} 2017$ ). On a similar approach to authority in the context of international law see Nicole Roughan's work (Roughan 2013). I believe this limitation of the service conception can be avoided if authority is conceptualised as being mediated or unmediated, which is discussed below. Raz (and, to a significant degree, Roughan) treat mediated authority as its central case, which I believe offers too limiting perspective.

${ }^{30}$ This scheme only applies to the relations of practical authority, not to the scheme of epistemic, or theoretical, authority, since the latter does not per se create any duty for those subjected to it. The difference between the two is that while theoretical authorities, such as experts or academics, can tell what should be done, practical authorities tell it to be done ( $\operatorname{Raz} 2006$, p. 1032-1034).
} 
authority of parents over their children, authority of officers over soldiers, authority of superiors over inferiors in a company, and, of course, authority of government over people. In all these instances, those in a position of authority may provide those subjected to it with special reasons for actions.

Reasons, ${ }^{31}$ in turn, are facts that count for performance of a certain action, or to put in more sophisticated words, 'a reason for an action is a consideration that renders its choice intelligible, and counts in its favor' (Raz 2006, p. 1006). Reasons may be simple ('I am hungry, and this is a reason for me to eat'), or complex and intertwined with other considerations or conceptions ('a low entrepreneurship activity is a reason for the government to lower the taxation burden'). Reasons reflect what ought to be done. They may have different weight; some reasons can outweigh others, and usually it is expected that an actor behaves accordingly to the optimal balance of reasons, i.e. according to what ought to be done all things considered.

An important feature of practical reasoning is that reasons exist on two levels, and thus there are first-order reasons and second-order reasons. Second-order reasons do not directly compete with first-order reasons, and if a conflict between a first- and a second-order reason happens, a first-order reason must be disregarded altogether and not weighed on its merits ( $\operatorname{Raz} 1999$, p. 39-45). An example for such a second-order reason is a promise. One ought to keep one's promises, no matter what. In such a way, if I gave a promise to help my friend, I must help him even if this is not what I ought to do according to the optimal balance of reasons (I might have other urgent things or I do not feel like helping him anymore, etc.). Second-order reasons of this kind are exclusionary in a sense that even if I have other reasons that compete with my promise, they must be excluded from my considerations, i.e. I must not act on them.

Norms $^{32}$ are another example of second-order reasons. Subjects ought to do as norms prescribe even if they have first-order reasons for non-compliance. Such competing first-order reasons are excluded and must not be taken into account, no matter how weighty they are. Norms, in this way, are protected reasons in a sense that they are reasons for action they prescribe, and at the same time they may not be appropriately defeated by excluded first-order reasons. For example, to say that the prohibition of the threat or use of force against territorial integrity or political independence of any state is a norm ${ }^{33}$ is to say that states consider it both as a reason for action (a reason for not treating or using the force against another state) and a reason for not acting for other competing reasons (for example, for reasons of gaining new territories or expanding political influence). First-order reasons that compete with the prohibition of the threat or use of force shall, therefore, be disregarded and must gain no weight in states' considerations as to what ought to be done. This example also clarifies another feature of norms as exclusionary reasons; they never exclude all the

\footnotetext{
31 Hereinafter I will refer to 'reasons for action' as to 'reasons' since another important class of reasons, reasons for beliefs, is not discussed here.

32 For the purposes of this article, I ignore the differences between norms and rules and use these terms as interchangeable, although not all rules are norms.

33 Charter of the United Nations (adopted 24 October 1945), 1 UNTS XVI, art. 2(4).
} 
competing reasons (i.e., norms are never absolute reasons). ${ }^{34}$ Thus, states may use force for the reasons of self-defence and authorisation by the UN Security Council. The exclusionary function of norms is a matter of social practices, and as practices evolve so do the norms; for instance, the discussions regarding the legality of humanitarian intervention can be said to rotate around the issue of whether certain moral reasons (solidarity, considerations of humanity, etc.) are altogether excluded by the general prohibition of the use of force. ${ }^{35}$

Unlike other types of authority, the authority of law is therefore normative, because it claims to provide its subjects with a special kind of protected reasonsnorms. ${ }^{36}$ Hence, we have come full circle. To say that the law ought to be obeyed is to say that the reasons it provides its subjects with are perceived by them as protected reasons. To put it in Raz's words, 'law is authoritative if its existence is a reason for conforming action and for excluding conflicting considerations' (Raz 2009, p. 29). This reinforces our initial claim that explanation of the rule of law depends on the theory of authority being used. For if we accept that law's existence makes a practical difference for those to whom it is addressed, there is a reasonable expectation that law's claims are to be met and perceived in such a way. According to this scheme, the rule of law is what actually enables the perception of the reasons the law offers as protected reasons, i.e. as norms. The rule of law bridges the gap between law's claim of normative authority and its acceptance as such by the subjects of law. What is peculiar, however, is that different types of legal orders claim and secure normative authority in dissimilar ways. This becomes especially visible when the normative authority of domestic law is compared to the normative authority of international law. These two kinds of the normative authority need a closer look.

The manner in which the claim of normative authority is addressed to the subjects affects the conditions under which this claim is accepted, i.e. the construction and the content of the rule of law. My hypothesis is that law's claim of authority may have two main forms: mediated and unmediated, which differ in the way the claim of authority is addressed to the subjects. ${ }^{37}$

The authority of law within the domestic context is often a euphemism for the authority of state since state government usually is the only legitimate power that has a universal claim of authority over all relations within society. ${ }^{38}$ Therefore, a

\footnotetext{
34 For an in-depth discussion of norms and their exclusionary function see Joseph Raz (Raz 1999, ch. 2).

35 This dynamics of practical reasoning and relations between first- and second-order reasons are essential for legal interpretation (Gorobets 2020).

36 Not all protected reasons are norms. Promises, voluntary obligations, commands are also protected reasons but not necessarily norms.

37 Mediated and unmediated forms of authority should not be taken as in an either/or manner. Rather, they exist on the opposite sides of a scale. Some claims of authority may be more mediated whereas other more unmediated. It is always a matter of degree. Also, it may be the case that law tends to adopt mediated form of authority due to features of legality. This issue cannot be discussed here, and it suffices to say that introduction of mediatory institutions may indeed be conducive to law's authority (Shapiro 2011, p. $170 \mathrm{ff}$ ), but I do not think it necessarily implies that unmediated authority is per se weaker or more primitive.

38 This must not be misapprehended. That the state and the domestic law claim to have authority over all relations within society does not mean that they actually have this authority. Different societies in differ-
} 
normal way of describing the authority of domestic law is by identifying it with the system of officials and corresponding system of public institutions ('authorities'). This type of authority strongly relates to the idea of 'authorship' in a sense that in domestic legal systems law is typically identified through the institutions empowered of making and applying laws. Within a domestic legal system, accepting the law's claim of the normative authority means accepting the authority of officials who make, interpret, apply, and enforce the law. In such a way, law's authority in domestic legal orders is by and large performed through institutions and officials. ${ }^{39}$ For this reason, I will refer to it as 'mediated authority'.

In the international realm, however, law's claim of authority is not typically backed by an institutional structure similar to the government in states-one of the most widespread arguments against the international rule of law. ${ }^{40}$ International law does not always embody or represent a consolidated or even articulated political power (though it can). Certainly, many parts of international law do rely on the institutional structures, such as international organisations, but these do not exhaust the entirety of norms of international law. Customary international law, and also significant number of international treaties, claim the normative authority without being identified, in one way or another, with some public institutions which issue or enforce them. According to Mario Prost, 70-75\% of all international treaties are bilateral treaties (Prost 2012, p. 36), which typically do not provide for any sort of institutional mediation. Even though the last couple of decades evidenced the boom of international organisations, the larger part of international law claims authority without mediation by officials or formal institutions. ${ }^{41}$ For this reason, I will call the authority of international law 'unmediated authority'.

Both types of authority-mediated and unmediated-represent normative authority. International law's authority, just like the authority of domestic law, is based on its claims that it accumulates and provides its subjects with protected reasons for action-norms. The difference between the two types, though, is that the authority of domestic law is far more mediated by officials and public institutions, whereas the

Footnote 38 (continued)

ent times practiced a variety of methods of limiting such a claim and securing at least some autonomous fields where the state has no power (Green 1990; Raz 2017).

39 This, again, is a matter of degree. I do share Fuller's conviction that any legal order must have a horizontal dimension, as well (Fuller 2001). The image of mediated authority, however, relates to the concept that legal systems require a division between officials and ordinary individuals. I discuss this more below. 40 The absence of a unified institutional structure is often taken as signalising the lack of authority of international law or international law's inability to have a claim to authority. This view is analysed and criticised by Başak Çalı (Çalı 2019) See also conceptualisations of the international rule of law through the prism of constitutionalism, where it is taken as applied primarily to institutions (Fassbender 2018; Kumm 2017).

41 Besides, it is not at all given that international organisations are functionally similar to formal institutions comprising of officials like those we see in domestic law. Only some international bodies (e.g., international courts, the UN Security Council, European Commission) may be said to perform functions similar to domestic formal institutions. International law, then, generally does without them (Lefkowitz 2017 , p. 261). See also Mario Prost's discussion on redundancy of the idea of officials and formal institutions as applied to international law (Prost 2012, p. 83-105). 
authority of international law is generally not. ${ }^{42}$ Hence, international law's normativity is typically directly created by, and addressed to its subjects, ${ }^{43}$ while domestic law's authority and normativity are mainly communicated through officials. ${ }^{44}$ Terry Nardin also observes that to speak about the international rule of law means to accept that authority of international law may be accounted for with no reference to officials:

we must assume... that law can be effective without legislation, adjudication, and centralised enforcement - that laws can be created, their meanings in particular cases authoritatively determined, and observance secured in other ways (Nardin 2008, p. 398).

That the normative authority of international law is by and large unmediated and its claim is addressed directly to its subjects, implies that the conditions under which this claim is acceptable and realisable differs from those which are germane to the mediated structure of authority. Our attempt of reverse engineering, therefore, brought us to the image of the rule of law as a set of conditions under which reasons addressed by law to its subjects are taken as protected ones. These conditions are not universal and depend on the structure of authority the law claims to have. Now we must investigate how this influences the concept of the rule of law as applied to international law.

\footnotetext{
42 This difference can be translated into the language of law/legal system duality. Herbert Hart famously claimed that international law is not a legal system, which was taken by many international lawyers as a denial of legality of international law, or at least as a sign that international law is less of a law than domestic legal orders (Payandeh 2010). However, what Hart seemed to mean is that legal system is only a mode of existence of law; a mode that is the most typical one because of its prevalence. Existence of secondary rules and officials, though, 'is not a necessity, but a luxury, found in advanced social systems whose members not merely come to accept separate rules piecemeal, but are committed to the acceptance in advance of general classes of rule, marked out by general criteria of validity' (Hart 1994, p. 235). International law seldom functions through officials exactly because it is not a legal system. I fully endorse David Lefkowitz's view on this matter, as well as his critique of Mehrdad Payandeh's reconstruction of Hart (Lefkowitz 2017).

${ }^{43}$ Cf. Waldron (2011, p. 332).

44 This view requires adopting a conception of legality which does not make law contingent on a particular source lying outside the law itself. In this regard, I generally share Jutta Brunnée's and Stephen Toope's perspective that 'both order and authority come from within law, from continuing practices that meet conditions of legality', and such "circular" understanding of legality, in which authority is internal to law, leads to a more robust account of the rule of law than a "linear" understanding', in which law's origin and authority have an external, non-legal source (Brunnée and Toope 2017, p. 170-171). At the same time, I do not share their conviction that the rule of law is essentially tantamount to the conditions of legality (and vice versa) as I incline to adopt a functional understanding of legality (Shapiro 2011). Intricacies of legality lie beyond the scope of this paper, yet some clarifications are still necessary. According to the functional understanding of legality, legal normativity differs from general social normativity in that it allows to bypass moral disagreements by providing its subjects with protected reasons for action. Note that such a conception of legality does not necessarily imply a clear-cut threshold between law and non-law, since norms can be more or less successful in performing this function. Yet the analytical value of the distinction does not suffer from this.
} 


\section{The International Rule of Law and Features of the Normative Authority}

In the previous two sections, I attempted to address some concerns about the concept of the international rule of law. In doing so, I suggested that the domestic and the international versions of this idea should not be deduced from one another, but instead must be treated as rooting in the common core which is the law's normative authority. From this, the rule of law-domestic, international, or any other-is a meta-normative ideal that reflects the merits of a legal order as functioning in a way which enables its subjects to effectively comply with it and use it as a guidance for actions. ${ }^{45}$ This merit may be achieved and secured in a variety of ways, which also explains the existence of distinct yet functionally overlapping concepts and doctrines. ${ }^{46}$ I shall now illustrate how and in what respect the international rule of law differs from its domestic images regarding the ways of achieving and securing its normative authority.

A critical outcome of excluding officials and public institutions from the equation of the international rule of law, which, as was shown in the previous section, is of primary importance, is that the strict separation between its 'thin' and 'thick' versions is no longer relevant; at least, this is so according to the image of the rule of law known domestically. The logic of the 'thin' and the 'thick' rule of law, as Pauline Westerman accurately observes, implies that in order to get thick, one must first be thin (Westerman 2018, p. 141). The rule of law cannot, therefore, be built from its thicker end. ${ }^{47}$ Because domestic law is issued, interpreted, applied, enforced, etc. dominantly through a system of officials, it is of paramount importance from the rule of law perspective that their practices are known, consistent through time, and conducted within reasonable frames of discretion, etc., otherwise its addressees may be unable to comply with it and guide their behaviour by it. These requirements also enable a justification of institutional authority of the state according to one or

\footnotetext{
45 I do not claim that this formula is a definition of the rule of law. There can be other, probably much more accurate and precise formulations of the idea. Yet my claim is that this is the understanding of the rule of law that enables its consistent and uncontroversial application to any legal order without falling into fallacies of domestic analogies. Also, this understanding allows to account for different manifestations of the rule of law in the variety of contexts. That is, both vertical and horizontal dimensions of the international rule of law can be reconstructed via normative authority.

46 Here, one can mention French l'êtat de droit, or German rechtstaat, or Soviet законность, or other iterations of this idea in different cultures. Some of them more convergent, some are not. Thus, Venice Commission emphasised that most European doctrines that relate to this merit of legal orders are largely overlapping. See Venice Commission, 'Report on the Rule of Law' (4 April 2011) CDLAD(2011)003rev, paras. 7-16. Yet non-European images of law and its merits may feature quite significant dissimilarities. My hypothesis suggests that the offered formulation of this merit is consistent with most cultural iterations of the rule of law and its conceptual siblings.

47 Brian Tamanaha famously arranged six modifications of the rule of law theories from simpler to more complicated, where each next one broadens and supplements the previous one. This is a one-way logic, and one may not simply reverse it and start discussing the rule of law 'as a welfare state' without first accounting for the rule of law 'as rule by law' (Tamanaha 2004, ch. 7-8). This, however, is not only a theoretical issue, as same also applies to implementing the rule of law in a legal system; without securing the formal legality the use of the rule of law for pursuing noble goals risks resulting in totalitarianism.
} 
another moral standard. Yet the rule of law does not require democracy or a liberal political setup, and hence such practices, even when conforming to these requirements, do not necessarily serve a morally justified goal. ${ }^{48}$ For this reason, the rule of law does not guarantee liberty, diversity, democracy, or equality. Its ideal is to enable law's claim for normative authority to be fulfilled.

Therefore, the thickening of the rule of law as a political doctrine only becomes possible when legal accountability of officials is socially secured, and when their directives meet the requirements of formal legality. Such social conditions usually enable (more or less) effective mechanisms of communicating the values and goals to the officials and transforming them first into policies and later into legal norms. This is one of the reasons why, for instance, populism as a political platform is a threat to the rule of law, ${ }^{49}$ as it values the achievement of certain goals far more than the way in which to achieve such goals. 'Doing the right thing' gets much more weight than 'doing things right', which may cause non-conformity with the basic formal requirements of the rule of law. In other words, the domestic logic of thickening of the rule of law entails that furthering morally justifiable goals and values does not in itself signifies the conformity to the rule of law, since such goals and values may as well be furthered through a deeply wicked institutional structure. At the same time, non-furthering of such goals and values does not mean non-conformity to the rule of law.

In international law, the situation differs, although the starting point remains the same. As stressed by Mattias Kumm, the international rule of law primarily entails

that nations, in their relationships to one another, are to be ruled by law. The addressees of international law, states in particular, should obey the law. They should treat it as authoritative and let it guide and constrain their actions (Kumm 2003, p. 22). ${ }^{50}$

Here again, the central message of the international rule of law is articulated through international law's claim for authority. Kumm's statement, however, lacks an important detail significant for reconstructing the international rule of law through authority, namely, that not only states should treat international law as authoritative or let it guide their actions, but also that international law as such must meet conditions for such a treatment. Authority is always a two-way relation between a legal order and its subjects. What changes during our shift from mediated authority of domestic law to unmediated authority of international law, however, is the perception of typical devices used to justify norms as protected reasons.

As suggested above, the authority of international law does not generally feature mediators in the form of officials. This primarily entails that norms of international

\footnotetext{
${ }^{48}$ Hence an iconic, yet often taken wrongly, statement by Raz that 'a non-democratic legal system, based on the denial of human rights, on extensive poverty, on racial segregation, sexual inequalities, and religious persecution, may, in principle, conform to the requirements of the rule of law better than any of the legal systems of the most enlightened Western democracies' (Raz 2009, p. 211).

49 See, for example, Andreas Zimmermann (Zimmerman 2018). Certainly, populism is only an example here. Many contemporary political and legal ideologies bring similar threats (Westerman 2018, ch. 8).

50 For the same argument, see also André Nollkaemper (2009, p. 77-78).
} 
law are not commonly justified by reference to institutions though this is also possible in some regimes. This also results in ways legal obligations get generated and what conditions their acceptance. When authority is mediated, the justification of obligation pertains to the delegation of judgment, when public institutions are supposed to weigh all the relevant reasons for action and balance them in legally valid norms (Raz 1999, p. 74). Importantly, such a delegation assumes that the end result of institutions' practical deliberations must be accepted as a content-independent reason for action, that is, 'the fact that an authority requires performance of an action is a reason for its performance which is not to be added to all other relevant reasons when assessing what to do, but should exclude and take the place of some of them' (Raz 1986, p. 46). Mediated structure of legal authority necessarily implies content-independence of its directives, ${ }^{51}$ i.e. the addressees of this directives must accept them without judging them on the merits. This is why traditional domestic doctrines of the rule of law make such an emphasis on formal legality, for it allows to secure that authorities, in their practical deliberations, account for at least some relevant reasons (not necessarily substantive ones). ${ }^{52}$

Norms of international law, especially norms of customary international law, are more often justified as devices enabling and securing coordination, as well as timeand labour-saving or error-eliminating devices. ${ }^{53}$ An important feature of these justificatory devices is that they usually relate to norms deliberated by their subjects directly. ${ }^{54}$ This in itself changes the scheme of normative authority. The authority of a norm of international law does not solely depend on its source or even on the many formal qualities which are of crucial importance for the domestic setup. Since states determine the content of the norms they abide by because they directly participate in their creation (either through conventional law-making or through customary practices), the authority of these norms equally depends on their formal and substantive merits, and often the lack or deficiency of the former is compensated by unanimity regarding the latter. If in domestic law, individuals cannot dis-obligate themselves from compliance with laws they dislike or disagree with (apart from the

\footnotetext{
51 Content-independence of authoritative directives is at the core of jurisprudential investigations of legal normativity (Adams 2017; Gur 2018; Raz 1986; Shapiro 2011). It is far beyond the scope of this article to discuss this concept in full. I wish to merely indicate that content-independence is to a large extent a feature of norms generated by institutional authorities, which by definition belong to the meditated kind. Whether unmediated authority generates content-independent reasons is not at all that clear. My hypothesis is that legal norms may have a thinner or thicker 'pre-emptive veil', that is, they can replace underlying reasons for action with a varying success. Mediated authority, because it assumes delegation of practical deliberation, tends to generate norms with a thicker pre-emptive veil than unmediated authority.

52 This issue relates to so called 'double-counting': accepting an authoritative directive as a reason for action and acting for some reasons that this directive accounts for is erring in practical reasoning. That is, one either trust an authority that it has balanced all reasons adequately and accepts its judgment, or one does not and acts for underlying reasons instead. What formal legality brings, then, in the context of mediated authority, is not that relevant reasons are counted twice, but rather that it is ensured that they are at least counted once. See also (Shapiro 2004, p. 414).

53 On different justificatory devices for norms, see Joseph Raz (1999, p. 59-65).

54 See, for details, Donald Regan's inquiry into the nature of such justifications of norms (Regan 1989, p. 995-1095).
} 
special cases like civil disobedience), nor can they cherry-pick laws to be bound by. In international law states can do this far more freely. ${ }^{55}$ Besides, since states do not delegate practical deliberations, but instead perform them directly, it affects the ways in which reasons (both first- and second order) are assessed. Unmediated authority generates legal obligation that are not necessarily content-independent, or at least when they are, states are entitled to penetrate through the pre-emptive veil freely. ${ }^{56}$

Because the authority of international law is of unmediated kind, the international rule of law does not require the logic of thickening and hence there is often a small gap between formal and substantive requirements of the international rule of law. The value-driven requirements of the international rule of law matter as much as requirements of formal legality. ${ }^{57}$ Since international law-making and, to a large extent, international law-enforcement are not delegated to formal institutions, the formal and substantive merits of international law converge and intertwine when it claims the authority. From this perspective, what Ian Hurd considers as a vice of international law regarding the rule of law, namely that states are free to choose the legal obligations they see reasonable to be bound by, at least in terms of treaty law (Hurd 2014, p. 41-42), can in fact be its virtue. States are entitled to assess norms of international law both by their formal qualities and by their substance when forming a pull of legal obligations applied to them.

\footnotetext{
55 This argument is certainly focused on obligations arising from international treaties. Even though the VCLT suggests a rather restrictive approach to unilateral withdrawals from treaties (Vienna Convention on the Law of Treaties (adopted 23 May 1969, entered into force 27 January 1980) 1155 UNTS 331, art. 56), it remains unclear whether this provision reflects customary international law and thus applies to the non-parties of the VCLT. Besides, most treaties do provide for denunciation or withdrawal. Also, with respect to the customary international law, states generally cannot directly dis-obligate themselves from it, unless replacing the obligations under the CIL with treaty-based legal regime (Simma and Pulkowski 2006). All this, however, does not impeaches the general observation that states have far more freedom and flexibility in choosing the legal obligations to be bound by than any individual could ever dream of.

56 That unmediated authority of international law may generate content-dependent obligations is very visible in the context of jus cogens. Art. 53 of the Vienna Convention on the Law of Treaties, by stating that a norm of jus cogens is 'a norm accepted and recognized by the international community of States as a whole as a norm from which no derogation is permitted and which can be modified only by a subsequent norm of general international law having the same character' does not in fact establish any formal threshold for peremptory norms. As the International Law Commission put it, 'it is not the form of a general rule of international law but the particular nature of the subject-matter with which it deals that may [...] give it the character of jus cogens'. ILC, 'Reports of the International Law Commission on the second part of its 17th session and on its 18th session' (3-28 January 1966) UN Doc A/6309/Rev.l. Yearbook of the International Law Commission (1966, Vol. II), 248. The authority of peremptory norms of international law, then, is explicitly content-dependent, rather than content-independent.

57 This does not in itself mean that the international rule of law requires a 'thicker' view on the rule of law as such. For example, W. Bishop supposed that 'the concept [of the international rule of law] includes reliance on law as opposed to arbitrary power in international relations; the substitution of settlement by law for settlement by force; and the realization that law can and should be used as an instrumentality for the cooperative international furtherance of social aims, in such fashion as to preserve and promote the values of freedom and human dignity for individuals' (Bishop 1961, p. 553). This, it seems, is not an attempt to advocate a broad definition of the international rule of law, but an attempt to show that substantive merits of international law cannot be appropriately excluded from the equation of the international rule of law and must be given the same weight as formal merits.
} 
To recapitulate, that the authority of domestic law is mediated by officials makes its formal conditions more relevant, because subjects of law are committed to accept in advance specific types of official utterances as norms even if they are imperfect or even wrong on the balance of reasons. The authority of international law, however, is only in small part mediated by officials, which implies that, in principle, there is no general commitment to accept in advance any norm that meets certain formal criteria. ${ }^{58}$ Even when such commitment is expressed through consent, however, this is seldom general and much more often ad hoc. As a consequence, the body of legal obligations under international treaties is unique for every state, and the content of customary international law is by and large approved through practice. What this difference between the structures of authority entails is that in international law there is a small gap between reasons that apply to states and norms that reinforce these reasons and bolster coordination by providing shortcuts in practical reasoning. ${ }^{59}$ The normative system of international law, in such a way, is closer to the reasons that apply to states, and states are more flexible in articulating groups of interlocked reasons and the balance they have as norms.

Going back to the international rule of law, the described features of the normative authority affect the structure and the content of the rule of law applied internationally. Formal and substantive merits of laws, which in the domestic setup are stored in different baskets, so to speak, get mixed together as pieces of Lego, and different areas or regimes of international law rely more on one pieces, whereas other regimes rely more on other pieces. ${ }^{60}$ The fundamental core of the rule of law - that the subjects of law must obey the law and be guided by it - is therefore enabled by both formal and substantive merits. ${ }^{61}$ States as the central subjects of international law recognise its authority by subjecting themselves (and to a significant degree each other) to the body of rules of conduct that represent a certain balance of reasons that apply to them. These rules generate authority and are complied with because they provide for a formally and procedurally reliable normative framework of conduct or dispute settlement, but they may as well generate it because they

\footnotetext{
58 These criteria also less sharp than in most domestic legal orders. If for the international treaties things are clear, the debates around criteria and markers of customary international law has proven to be endless. A highly careful language adopted by the International Law Commission in this regard also suggests that the criteria used for identification of the customary international law are quite vague. ILC, 'Draft conclusions on identification of customary international law' UN Doc A/73/10, para. 65.

59 Since norms by definition exclude some reasons from deliberations, this means that actors no longer need to consider all of them every time this is relevant and needed. Norms already represent a certain balance of excluded reasons and remain valid protected reasons even when this balance is tipped.

60 Richard Collins speaks of a similar duality of the international rule of law, and he pictures these two sides of the international rule of law as "justified by quite distinctive logics, but their mutual antagonism makes them also inseparable in expressing urges that make little sense except in their opposition: the functional vision expressing the need to avoid an over-fetishised legal formalism that tends to mask structural inequalities, biases and global injustices; the formal vision ensuring a degree of accountability and restraint that can only be ensured through the systematic logic of the international legal form itself' (Collins 2019, p. 225).

61 Cf. Watts (1993), McCorquodale (2016, p. 292 ff).
} 
express values and principles shared by states, even when the formal qualities of such expressions are dubious.

\section{Conclusions}

In this article, I attempted a reconstruction of the concept of the rule of law in a way that allows one to account for its main manifestations-domestic and international. I submitted that the rule of law should be considered as part and parcel of a conception of normative authority, and that what is traditionally approached as requirements or principles of the rule of law are in fact conditions under which a claim for authority of a certain normative order is realisable. What does this entail, and how does it change our perception of the international rule of law?

My central conclusion is that an image of the rule of law, its content and function depend on how a certain legal order generates the obligation to obey its norms and use them as guidance for action. The rule of law is therefore a collage of qualities of norms that enable or contribute to their status as authoritative. In the case of the international rule of law, this collage combines both formal and substantive merits of norms, securing in such a way status of states as both agents and addressees of international law. The international rule of law should be considered independently from the domestic rule of law, since the latter depends on dissimilar tools and techniques of justification of norms, and hence the structure of domestic law's authority differs quite significantly from the one of international law. Still, both versions of the rule of law enable furthering of certain values and principles, since they both protect subjects of law from the threats of the law itself. If conditions under which a legal order's claim for authority is realisable (and these conditions differ depending on the type of legal order), this allows for securing liberty and autonomy of its subjects and for conforming to principles legitimising this legal order.

That authority of law can be justified, secured, and made realisable by different means and under different conditions allows to break the vicious circle of domestic analogy, when the international rule of law inherits conceptual features of the rule of law known domestically, which leads to distortions or limitations. Both domestic and international rule of law represent the idea that legal orders, by claiming practical authority, must meet conditions under which this claim is justified and realisable. Since authority of law may be more or less mediated by formal institutions, this also affect what these conditions are and how they can be met.

Acknowledgements This paper was presented at ESIL Research Forum 'The Rule of Law in International and Domestic Contexts: Synergies and Challenges' (Göttingen, 4-5 April 2019). I would like to thank Prof Marcel Brus, Andreas Hadjigeorgiou, Dr Till Patrik Holterhus, Dr André de Hoogh, and Prof Pauline Westerman, as well as participants of the Research Forum for their invaluable feedback on the early drafts of the paper. I am also grateful to three anonymous reviewers for their thoughtful and constructive comments and suggestions, which helped me to clarify some critical ideas used in this paper.

Open Access This article is licensed under a Creative Commons Attribution 4.0 International License, which permits use, sharing, adaptation, distribution and reproduction in any medium or format, as long as you give appropriate credit to the original author(s) and the source, provide a link to the Creative Commons licence, and indicate if changes were made. The images or other third party material in this article 
are included in the article's Creative Commons licence, unless indicated otherwise in a credit line to the material. If material is not included in the article's Creative Commons licence and your intended use is not permitted by statutory regulation or exceeds the permitted use, you will need to obtain permission directly from the copyright holder. To view a copy of this licence, visit http://creativecommons.org/licen ses/by/4.0/.

\section{References}

Adams N (2017) In defense of content-independence. Legal Theory 23:143-167

Anghie A (2005) Imperialism, sovereignty, and the making of international law. Cambridge University Press, Cambridge

Beaulac S (2007) An inquiry into the international rule of law. EUI Working Paper MWP 1-35. http:// hdl.handle.net/1814/6957

Bingham T (2007) The rule of law. Camb Law J 66:67-85

Bingham T (2011) The rule of law. Allen Lane, London

Bishop WW (1961) The international rule of law. Mich Law Rev 59:553-574

Brunnée J, Toope S (2010) Legitimacy and legality in international law: an interactional account. Cambridge University Press, Cambridge

Brunnée J, Toope S (2017) Interactional legal theory, the international rule of law and global constitutionalism. In: Lang A, Wiener A (eds) Handbook on global constitutionalism. Edward Elgar, Cheltenham, pp 170-182

Buchanan A (2006) Democracy and the commitment to international law. Ga J Int Comp Law 34:305-322

Burgees P (2019) Deriving the international Rule of Law: an unnecessary, impractical and unhelpful exercise. Transnatl Leg Theory 10:65-96

Çalı B (2019) Authority. In: d'Aspremont J, Singh S (eds) Concepts for international law: contributions to disciplinary thought. Edward Elgar, Cheltenham, pp 39-53

Chesterman S (2008) An international rule of law? Am J Comp Law 56:331-361

Collins R (2019) Two idea(1)s of the international rule of law. Glob Con 8:191-226

Craig PP (1997) Formal and substantive conceptions of the rule of law: an analytical framework. Pub Law, pp 467-487

Crawford J (2003) International law and the rule of law. Adel Law Rev 24:3-12

Dicey AV (1959) Introduction to the study of the law of the constitution, 10th edn. Macmillan, London

Dworkin R (1985) A matter of principle. Harvard University Press, Cambridge

Dyzenhaus D (2014) Hobbes on the international rule of law. Ethics Int Aff 28:53-64

Fassbender B (2018) What's in a name? The international rule of law and the United Nations Charter. Chin J Int Law 17:761-797

Fuller LL (1978) The morality of law, Rev edn. Yale University Press, New Haven

Fuller LL (2001) Human interaction and the law. In: Winston K (ed) The principles of social order: selected essays of Lon L. Fuller. Hart Publishing, Portland, pp 231-266

Gorobets K (2020) Practical reasoning and interpretation of customary international law. In: Merkouris P, Kammerhofer $\mathbf{J}$ (eds) The theory and philosophy of customary international law and its interpretation (forthcoming)

Gowder P (2016) The rule of law in the real world. Cambridge University Press, New York

Green L (1990) The authority of the state. Clarendon Press, Oxford

Gur N (2018) Legal directives and practical reasons. Oxford University Press, Oxford

Guth AH (2000) The inflationary universe: the quest for a new theory of cosmic origins. Addison-Wesley Longman, Boston

Hart HLA (1994) The concept of law, 2nd edn. Oxford University Press, Oxford

Hurd I (2014) The international rule of law: law and the limit of politics. Ethics Int Aff 28:39-51

Hurd I (2015a) The international rule of law and the domestic analogy. Glob Con 4:365-395

Hurd I (2015b) Three models of the international rule of law. Eidos 23:37-48

Kanetake M (2016) The interfaces between the national and international rule of law: a framework paper. In: Kanetake M, Nollkaemper A (eds) The rule of law at the national and international levels: contestations and deference. Hart Publishing, Oxford, pp 11-41 
Koskenniemi M (2006) From apology to utopia: the structure of international legal argument, 2nd edn. Cambridge University Press, Cambridge

Koskenniemi M (2016) Expanding histories of international law. Am J Legal Hist 56:104-112

Krygier M (2012) Why the rule of law is too important to be left to lawyers. Law Soc Bounds 2:30-52

Krygier M (2018) Why the rule of law matters. Jurisprudence 9:146-158

Kumm M (2003) International law in national courts: the international rule of law and the limits of the internationalist model. Va J Int Law 44:19-32

Kumm M (2017) Global constitutionalism and the rule of law. In: Lang AF, Wiener A (eds) Handbook on global constitutionalism. Edward Elgar, Cheltenham, pp 197-211

Lefkowitz D (2017) What makes a social order primitive? In defense of Hart's take on international law. Leg Theory 23:258-282

Lubman D (2010) Rule of law and human dignity: re-examining Fuller's canons. HJRL 2:29-47

McCorquodale R (2016) Defining the international rule of law: defying gravity? Int Comp Law Q 65:277-304

Nardin T (2008) Theorising the international rule of law. Rev Int Stud 34:385-401

Nollkaemper A (2009) The Internationalized rule of law. HJRL 1:74-78

Oakeshott M (1983) The rule of law. On history and other essays. Barnes and Noble, Totowa, pp 119-164

Pahuja S (2011) Decolonising international law: development, economic growth, and the politics of universality. Cambridge University Press, Cambridge

Pavel CE (2019) The international rule of law. Crit Rev Int Soc Polit Philos 22:1-20

Payandeh M (2010) The concept of international law in the jurisprudence of H.L.A. Hart. EJIL 21:967-995

Prost M (2012) The concept of unity in public international law. Hart Publishing, Oxford

Raz J (1986) The morality of freedom. Oxford University Press, Oxford

Raz J (1999) Practical reason and norms, 2nd edn. Oxford University Press, New York

Raz J (2006) The problem of authority: revisiting the service conception. Minn Law Rev 90:1003-1044

Raz J (2009) The authority of law: essays on law and morality, 2nd edn. Oxford University Press, New York

Raz J (2017) Why the state? In: Roughan N, Halpin A (eds) In pursuit of pluralist jurisprudence. Cambridge University Press, Cambridge, pp 136-162

Regan DH (1989) Authority and value: reflections on Raz's Morality of Freedom. South Calif Law Rev 62:995-1095

Roughan N (2013) Authorities: conflicts, cooperation, and transnational legal theory. Oxford University Press, New York

Sampford C (2014) "Thin theories" of domestic and international rule of law. In: Popovski V (ed) International rule of law and professional ethics. Ashgate, Farnham, pp 49-76

Shapiro SJ (2004) Authority. In: Coleman J, Himma KE, Shapiro SJ (eds) The Oxford Handbook of Jurisprudence and Philosophy of Law. Oxford University Press, Oxford, pp 382-439

Shapiro SJ (2011) Legality. Harvard University Press, Cambridge

Simma B, Pulkowski D (2006) Of planets and the universe: self-contained regimes in international law. EJIL 17:483-529

Tamanaha BZ (2004) On the rule of law: history, politics, theory. Cambridge University Press, Cambridge

Tasioulas J (2018) The rule of law. King's College London Law School Research Paper 21:1-23. https:// ssrn.com/abstract $=3216796$

von Hayek FA (2012) Law, legislation and liberty: a new statement of the liberal principles of justice and political economy. Routledge, London

Waldron J (2011) Are sovereigns entitled to the benefit of the international rule of law? EJIL 22:315-343

Watts A (1993) The international rule of law. German YB Int Law 36:15-45

Westerman PC (2018) Outsourcing the law: a philosophical perspective on regulation. Edward Elgar, Cheltenham

Zimmerman A (2018) Times are changing - and what about the international rule of law then? EJIL: Talk! https://www.ejiltalk.org/times-are-changing-and-what-about-the-international-rule-of-lawthen/. Accessed 12 Feb 2019

Publisher's Note Springer Nature remains neutral with regard to jurisdictional claims in published maps and institutional affiliations. 